\title{
IAMJ
}

INTERNATIONAL

AYURVEDIC

MEDICAL JOURNAL

Review Article

ISSN: 2320-5091

Impact Factor: 6.719

\section{ROLE OF AUSHADHA SEVAN KAAL IN AYURVEDA COMPARATIVE TO CHRONO THERAPEUTICS}

$\underline{\text { Gayatri }}^{1}, \underline{\text { Suvitha S V}}{ }^{2}, \underline{\text { Sarika } \text { Yadav }^{3}}, \underline{\text { C. R. Yadav }}{ }^{4}$

${ }^{1}$ P.G Scholar, P.G Department of Kriya Sharir, National Institute of Ayurveda, deemed to be University (de-novo), Jaipur, Rajasthan, India

${ }^{2}$ P.G Scholar, P.G Department of Kriya Sharir, National Institute of Ayurveda, deemed to be University (de-novo), Jaipur, Rajasthan, India

${ }^{3}$ Assistant professor, P.G Department of Kriya Sharir, National Institute of Ayurveda, deemed to be University (de-novo), Jaipur, Rajasthan, India

${ }^{4}$ Associate professor \& H.O.D, P.G Department of Kriya Sharir, National Institute of Ayurveda, deemed to be University (de-novo), Jaipur, Rajasthan, India

Corresponding Author: angle.ayur@gmail.com

https://doi.org/10.46607/iamj3809082021

(Published Online: August 2021)

Open Access

(C) International Ayurvedic Medical Journal, India 2021

Article Received: 28/07//2021 - Peer Reviewed: 03/08/2021 - Accepted for Publication: 04/08/2021

Check for updates

\section{ABSTRACT}

According to Ayurveda Aushadha Sevan Kaal is the type of Avasthika Kaal. Kaal is an essential factor to consider when treating disease because it refers to the right timing of drug administration. Aushadha (medicine) is considered under Trisutra. According to Acharya Charaka, Aushadha having reverse properties of Desha (Habitat), Matra (Dose) and Kaal (Time) can cure the diseases effortlessly. Our Acharya has enlightened the connection of Kaal and Dosha and suggested consideration while treating the patients. The precise timing at which patients take their medications is critical since it has a substantial impact on treatment outcomes. In Ayurveda, lots of Acharya has specified different Bhaishajya Kaal along with the Dosha, disease, general condition of the body, and in line with the type of preparations (Swaras, Kalka, Kwatha). Chrono Therapeutics is a term used in modern science to describe the concept of timed dose. It recommends synchronizing your medication schedule with your body's natural clock. Though treating a disease success can be attained only when there is a proper arrangement of Desha 
(Region), Kaal (Time), Pramana (Dosage), Satmya (Wholesomeness), Asatmya (Unwholesomeness), Pathya (useful) \& Apathya (harmful). In this study, an attempt was made to compare the Aushadha Kaal Prayoga with chronotherapeutics in modern science. The comparison was done on Aushadha Prayoga Kaal of certain diseases such as allergic rhinitis, asthma, rheumatoid arthritis, peptic ulcer, diabetes mellitus. Overall look, both are having similarities vs dissimilarities too.

Keywords: Aushadha Sevan Kaal, Bhaishajya, Chrono Therapeutics, Circadian rhythm.

\section{INTRODUCTION}

Kaal (time) is a crucial aspect in both good health and sickness. From the Nidana (causative factor) through the Chikitsa (therapy), each stage of an illness is circumscribed by Kaal. Kaal can be thought of as a change, and it is just one among several for various presentations and calculations ${ }^{1}$ and it is expressed as Dina (day), Masa (month) etc. Kaal is Bhagavan, Svayambhu (self-created), and its beginning, existence, and end are all unknown. It is that determines the individual's life and death. ${ }^{2}$ It is a continuous process like chakra (wheel) which does not stop even for a moment and joins both Sukha and Dhukha to the life of the individual. ${ }^{3}$ All forms of impacts are caused by Kaal, which is an exclusive and precise causal element. At the same time, it is unavoidable. As a result, Ayurveda being the science of life emphasizes the concept of Kaal. Kaal is classified as Niyat or Nityaga (continuous) and Aniyat or Awasthik $\mathrm{Kaal}^{4}$. All the Acharya's have established the relationship between Kaal and Aushadha in our classics. In Ayurveda explained Trisutra, Under the Trisutra, Hetu Lingh Aushadh is considered. In this trio, Aushadh has been given equivalent prominence as the earlier two. There are rhythmic changes in the predominance of Sharir Dosha with time. Therefore, when a medicine is given, it is similarly essential to proceeds into consideration Vaya, Agni Bala, Rogi bala, Roga bala, Ritu, etc. Aushadha sevan kaal is taken under Awasthik Kaal. Bhaishajya Kaal refers to the time when the medicine is administered. Alternative expression of Bhaishajya Kaal are Aushadha kaal, Aushadhaavekshan Kaal, Aushadha Avcharan Kaal, Agad Kaal Bhaishajya Graham Kaal. Aushadha Kaal is a vital tool for the administration of Aushadha; failure to use them may result in a serious discrepancy in treatment. Nowadays, the relationship is sometimes overlooked, particularly while administering medicine. As the Aushadha Dravya fails to show its full effect, such carelessness could be one of the therapies. Bhaishajya Kaal is defined in Ayurveda concerning food; they are solely for Shamana Chikitsa, and oral administration is the root of all Kaal. Agni, being the extreme aspect for maintaining Dhatu-samyata, all the remedies are directed to maintain and preserve the potency of Agni. The proper knowledge of Agni and food/drug interaction is helpful to attain a quick and sustainable relief for the patient. The biological processes of the body directly affect the pharmacokinetics and pharmacodynamics of Ayurvedic treatment. Many medications' efficacy is influenced by how long they are given. Predictable change in bodily functions during the day, season, and age has been mentioned in Ayurveda as altering the severity of disease symptoms, diagnostic test findings, and the impact of other therapies. Apart from this, the time of administration of medicine is equally important as the timed dosage is with assurance going to improve the treatment effect. 
Number of Aushadha Sevan Kaal mention by different Acharya in Ayurveda-

Table 1: Bhaishajya Kaal according to different Acharya

\begin{tabular}{|c|c|c|c|c|c|}
\hline s.no & Charak $^{5}$ & Sushruta $^{6}$ & Ashtang $^{7}$ hridayam & Ashtang ${ }^{8}$ sangraha & Sharangadhar ${ }^{9}$ \\
\hline 1 & Nirannam & Abhakta & Abhakta & Abhakta & Suryodaya(pratah) \\
\hline 2 & Bhuktadau (pratah) & Pragbhakta & Pragbhakta & Pragbhakta & Pragbhakta \\
\hline 3 & Bhuktadu (sayam) & Madhya Bhakta & Madhya Bhakta & Madhya Bhakta & \\
\hline 4 & Bhukta Madhya & Adhobhakta & Adhobhakta & Adhobhakta & Adhobhakta \\
\hline 5 & Bhukta paschat & Antarabhakta & & Antarabhakta & \\
\hline 6 & Bhakta sayuktam & Sabhakta & Sabhakta & Sabhakta & \\
\hline 7 & Samudga & Samudga & Samudga & Samudga & \\
\hline 8 & Muhurmuhu & Muhurmuhu & Muhurmuhu & Muhurmuhu & Muhurmuhu \\
\hline 9 & Grase & Grase bhakta & Grase Sagraasa & Grase Sagraasa & \\
\hline 10 & Grasantara bhakti & Grasantara bhakta & Grasantara bhakta & Grasantara bhakta & \\
\hline 11 & & & Nishi & Nishi & Nishi \\
\hline Total no. & 10 & 10 & 10 & 11 & 5 \\
\hline
\end{tabular}

Chrono-therapeutics refers to a treatment method in which in vivo drug availability is timed to match disease rhythms to optimize therapeutic outcomes and minimize side effects ${ }^{10}$. It is based on the observation that there is an interdependent relationship between peak-to-trough rhythmic activity in disease symptoms, risk factors, pharmacologic sensitivity, and pharmacokinetics of many drugs. ${ }^{11}$ In modern science, refers to the use of circadian or their rhythmic cycles of conditions symptoms of the individual being treated in the application of therapy. It means the administration of medication or treatment in matching with the body's circadian rhythm to maximize effectiveness and minimize side effects. Circadian (circa-about; dies, day or about 24 hours) oscillations in the biological, physiological, and behavioral functions of an organism with a periodicity of 24 hours. Chronotherapy is used in various clinical fields such as the treatment of asthma, cancer, hypertension, and multiple types of depression, among others seasonal affective disorders and bipolar disorders. ${ }^{12}$ The most advanced use of chronotherapy (drug chronotherapy) does not entail the use of new drugs, but rather the modification of existing ones. Simple adjustments like changing the dose schedule, reformulating a drug to postpone its entry into the bloodstream, and employing programmable pumps to deliver medicine at exact intervals could have a huge impact.

\section{DISCUSSION}

Description of Aushadha Sevan Kaal and Chrono therapeutics

\section{Abhakta Kaal (Niranna)-}

According to Acharya Chakrapani Abhakta means administration of Aushadha alone (without food) or before food in the morning or when eaten food has been digested properly ${ }^{13}$. Medicine should be given in the Kapha Udreka Gata Kaal, according to Acharya Hemadri. In this Acharya Indu ${ }^{14}$ states administration of medicine, it should be one Yama after sunrise. Synonyms-Abhakta, Ananna, Nirbhukta, Suryodaye Jate

Mode of action of Bhaishajya - Due to the absence of food, Agni and Bhaishajya 's interaction is unfettered. Acharya Sushruta says medicine becomes very powerful in the absence of food and so cures diseases without a doubt ${ }^{15}$. As in Abhakta Kaal stomach is devoid of Kapha thus the digestive fire digests the medicine completely and one gets the maximum benefits of the medicine. Later, the Vaidya should assess the patient's and disease's severity. If both are powerful (Balwan), this Kaal should be chosen. 
Indications $-\{$ Fig. 1$\}$

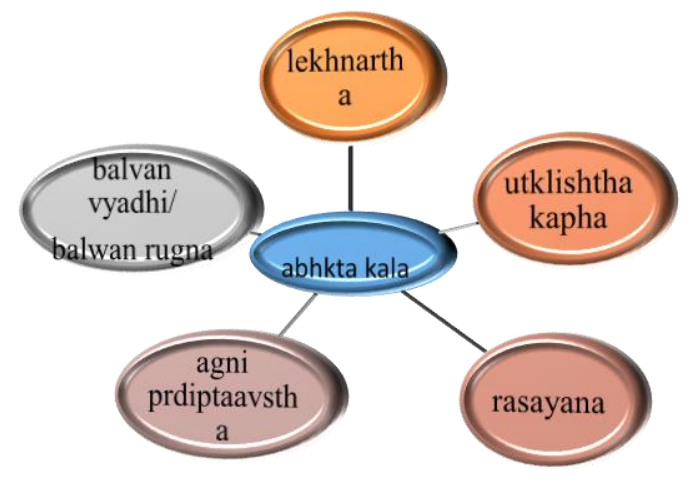

$\{$ Fig. 1\}

Contra-Indications-Children, Pregnancy, Female patients, and those who cannot withstand the potency of a medicine, Doshakshaya Awastha, Dhatukshaya.

Complications -If the medication is administered without considering the facts, then one must suffer from complications like Glani (loss of power) and even death.

\section{Pragbhakta Kaal-}

An Aushadha taken (on an empty stomach) just before a meal is called Pragbhakta. According to Hemadri, Bhaishajya intake is immediately followed by food.

Synonyms - Prak-bhojana, Annadau, Prag-bhakta, Bhojanagre, Bhuktadau, Poorvabhaktasya

Mode of action of Bhaishajya -Medicine took in Pragbhakta Kaal, will get digested without affecting the strength of a person. There is no Balakshaya since the Bhaishajya is followed by food, therefore it becomes Agni's initial target, rather than the food. No regurgitation of Bhaishajya occurs as it is covered over with the meal. The Amashaya and the vitiated Doshas are directly affected by Bhaishajya. ${ }^{16}$ It will help to cure the diseases related to the stomach. It works on the vitiated Doshas situated in Amashaya (stomach).
Indications $-\{$ Fig. 2$\}$

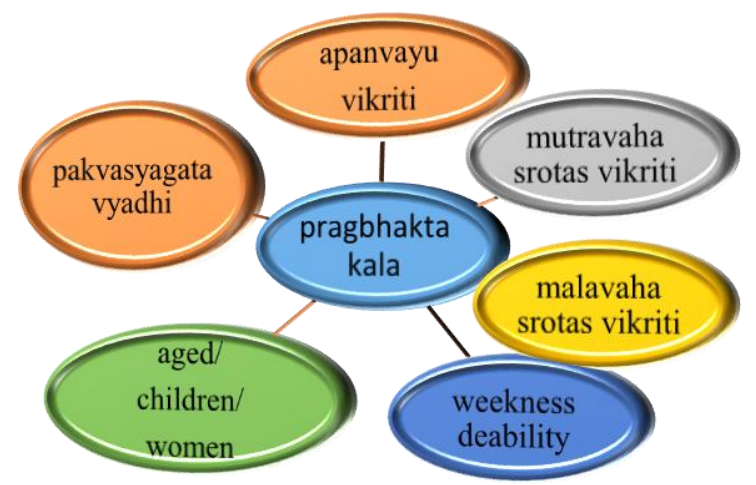

\{Fig.2\}

\section{Madhya Bhakta Kaal-}

Bhaishajya is taken in the course of a meal is called Madhyabhakta. This person is asking to consume half of his meal and then advised to have medicine and then the take remaining part of the meal is advised. Synonyms -Madhye, Madhye Bhaktam, Madhya Bhojana

Mode of action of Bhaishajya - Food restricts the Urdhwagati and Adhahgati of Bhaishajya, forcing them to act locally, which aids in the treatment of Sthanik Doshas. Both Samana Vayu and Pachaka Pitta are located in the Koshtha. After the consumed food firstly activates the process of digestion, which in turn triggers Samana Vayu and Pachaka Pitta. As a result, Saman Vayu will act over the medicine taken and helps to give the estimated result. Food is then consumed, which covers the medicine and prevents it from being spit out. The medicine used during this Kaal has a particularly strong effect on Samana Vata. Agni or Pachaka Pitta begins to function properly once this Samana Vata is improved. All Pittas are nourished by the Pachaka Pitta. All Pittas will function normally if Pachaka Pitta is corrected. This Kaal utility is in the control of Pittaja, Koshthagata Vyadhis, and Samanavayudushti. 
Indications- $\{$ fig. 3$\}$

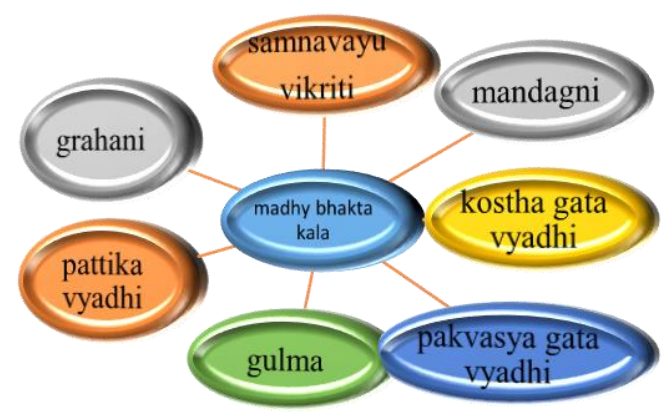

\{Fig.3\}

In Mandagni, Medicine is consumed in the middle of the meal to cure diseases of the middle part of the body, by not spreading (Avisari Bhava) out of the middle part (Kostha- elementary canal).

\section{Adhobhakta Kaal-}

According to the Acharya Administration of Bhaishajya in after the food is Adhobhaktam According to Hemadri and Indu, Bhaishajya is to be administered immediately after meals. In Vyana Vayu Vikruti, Bhaishajya is administered after lunch while in Udana Vayu Vikruti, it is administered after dinner. This Kaal is classified into two -

\section{Pratah Bhojana Kaal}

2. Sayam Bhojana Kaal

1. Pratah Bhojana Kaal - In this Kaal the medicine is administered after the morning meal and indicated for Vyana Vata Vikruti.

2. Sayam Bhojana Kaal - In this Kaal Bhaishajya is given after the evening meal, and indicated for Udana Vata Vikruti.

Synonyms: Pratah Ashasya, Pashchatbhakta, Ante, Adhaha.

Mode of action of Bhaishajya -Bhaishajya is advised to be administered in the Pratah Bhojana Kaal because the site of Vyana Vayu is considered as Hridaya (heart). This Bhaishajya will reach Hridaya and will act properly on Vyana Vayu. After lunch- stimulation of Vyana Vayu after the digestion of food and formation of Aahara Rasa. After that, the heart also gets languish after working for the whole day. So the activity of Vyana Vayu also hangs down in the night. The activities of Vyana are then occupied over by
Udana Vayu. Therefore, the administration helps to cure the diseases related to Udana Vata. After dinnerstimulation of Udana Vayu and Udana Vayu facilitates the Urdhvagati of Bhaishajya, it strengthens the upper part of the body, especially the sense organs.

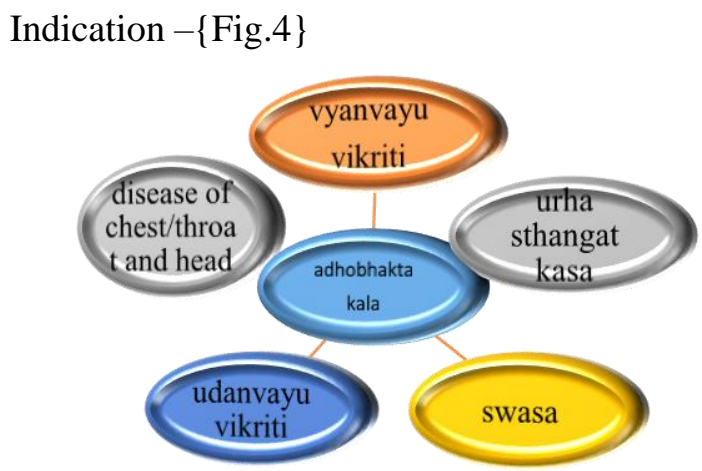

\{Fig.4\}

\section{Antarabhakta Kaal-}

Antarabhakta Kala is considered to be the administration of Bhaishajya between two meals. In this Kaal Bhaishajya is administered after digestion of afternoon meal, then, after digestion of medicine evening meal is taken. A similar regimen is followed between evening and morning meals. The second Antarabhakta Kaal, which is the same as Nishi Aushadhaa Sevan Kaal, is considered by Acharya Indu to be one Yama followed by the digestion of evening meal. Acharya Jejjat has categorized this Kaal under Madhyobhakta. Acharya Chakrapani has stated that in Antarabhakta Kaal the medicine is mixed with food or some eatables.

Synonyms: Antarabhaktam, Bhaktayormadhye.

Mode of action of Bhaishajya - It demonstrates the Hridya, Pathya, Deepana, and Manobalakara effects. Agni is stimulated as a result of Madhyanha, i.e. Pittakaal. In this Kaal, Bhaishajya is properly metabolised. 
Indications- $\{$ Fig-5 $\}$

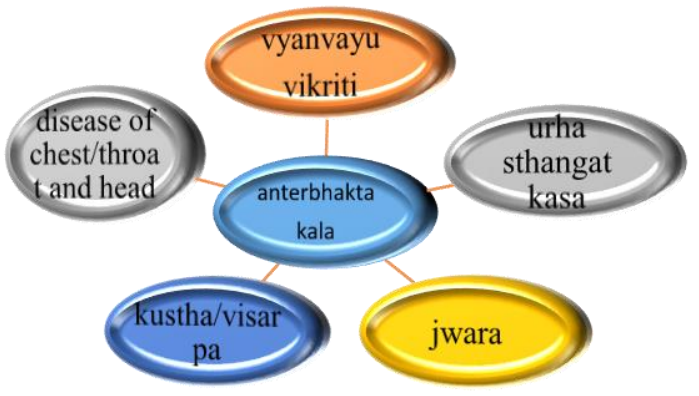

$\{$ Fig. 5$\}$

\section{Sabhakta kaal_-}

According to Acharyas, the administration of Bhaishajya is mixed with food or during the preparation of food. Acharya Indu also opines the same.

Synonyms -Bhakta Samyuktam, Sannam, and Samabhaktam.

Mode of action of Bhaishajya -To potentiate $A g$ nibala. Aushadha and Ahara will be digested, and Rasa will emerge, Vyana Vata will then circulate it throughout the body. In Rasadhatu Bhaishajya along with food and spreads Urdhva, Adhah, and Tiryak Gati circulate throughout the body, assisting in Sarvanga Samshrita Vyadhis. Medicine consumed between two morsels is cordial, donates strength to the mind, kindles digestion, and is always suitable.

Indications- $\{$ Fig-6 $\}$

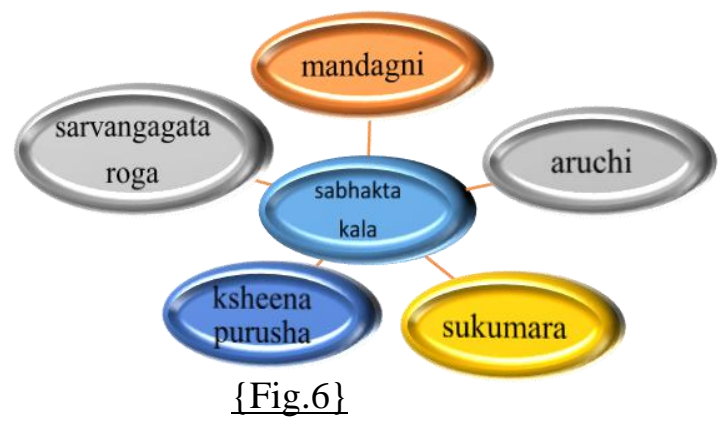

When food is processed with Aushadha; Teekshnata, strong odor, and the bad taste of Aushadha are reduced, it is used for administration in women, children, the elderly, people with low strength (Sukumara), and those who despise Aushadha. In Ksheena Purusha that Aushad Sevan Kaal protects their Bala.

\section{Sagrasa Kaal -}

Bhaishajya is taken with every morsel of food is called Sagrasa it is also known as Grase-Grase. In this Kaal Bhaishajya is to be blended with each bolus of food, according to Arunadatta and Hemadri. This is somewhat similar to Samudga Kaal. Sagrasa can be used when the drug is in the form of Churna (powder), Vatika (tablet), or Leha (liquid) (confections). Churna should be administered for increasing appetite in cases of weak patients. Vajikarniya Aushadha is also better administered in this form.

Mode of Action of Bhaishajya - Sagrasa Bhaishajya supports the absorption of Bhaishajya from the buccal mucosa. Direct absorption from the buccal mucosa into the systemic circulation provides a quick onset of action. The Pranavayu is stimulated by Grasa Kaal Bhaishajya. The Indriya and Chitta Prasadanas are thus performed. This improves Vrishya Dravyas' Prabhava.

Indications- $\{$ Fig. 7$\}$

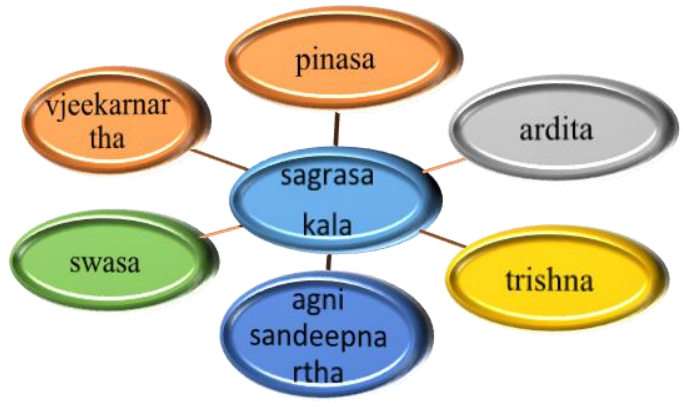

$\{$ Fig.7 $\}$

\section{Grasantara Kaal-}

Bhaishajya is administered each alternate morsel of food is called Grasantara Kaal. One bolus is consumed, followed by Bhaishajya, and then another bolus. Grasantara, also known as Kavalantare, is then taken of Aushadha in between each bolus of a meal. When administering the Vamaneeya Dhumapana, this is employed.

Mode of action of Bhaishajya- It advantages in the correction of the Gati (activity) Vikruti of Vata Dosha by promoting Anulomana of Vata Dosha. In this Kaal Aushad is in the form of powders, which are to be given to persons of weak digestion to in- 
crease digestive power and which are aphrodisiac should be given mixed with each morsel.

Indication- $\{$ Fig. 8$\}$

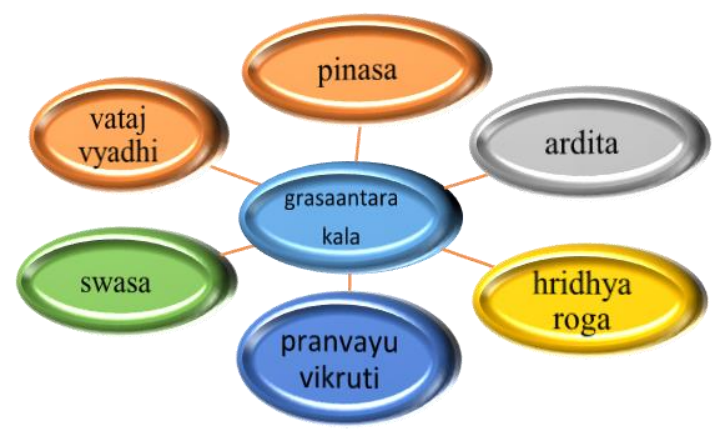

$\{$ Fig.8\}

\section{Samudga Kaal-}

A Bhaishajya is administered at the start and again at the end of a meal is called Samudga. The same is said by Acharya Indu and Hemadri. Dalhana emphasises the word 'Peeyate,' suggesting that Aushadha should be in liquid form so that food can be boiled down to a nutshell. It is also effective when the type of medication is Pana (liquid), Navana (given through nostrils), and Avaleha (confections).

Mode of action of Bhaishajya -This Kaal is best to mitigate the Doshas which have spread in both ways. It boosts the drug's Urdhva and Adhah Gati. It promotes Anulomana of Vata Dosha, which helps to correct the Gati (activity) Vikruti of Vata Dosha. In circumstances where the disturbed body Doshas take both an upward and downward route, this method of administration is more effective.

1) Hikka-Kapha and Vata Doshas are implicated in hikka. The Urdhva Sharir is home to Kapha, while the Adhah sharira is home to Vata. As a result, Bhaishajya in the Samudga Kaal balances the Doshas in the upper and lower body.

2) Akshepaka- Vata Doshas is implicated in Akshepaka. So Samudga Bhaishajya affects both of the body's extremities.
Indications- $\{$ Fig.-9\}

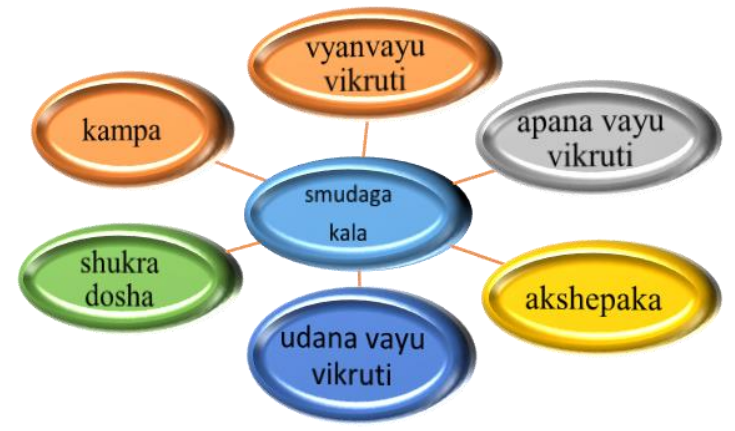

\{Fig.9\}

\section{Muhurmuhu Kaal-}

Bhaishajya is administered repeatedly at Muhurmuhu Kaal. Aushadha is taken regularly, with or without food. This Kaal can be broadly categorized into two-

\section{Abhakta Muhurmuhu 2. Sabhakta Muhurmuhu}

Based on the patient's Bala, the indication of with or without meals may have been made.

Mode of Action of Bhaishajya - Treats the Doshas that has been vitiated in their Sanchaya and Vegavastha. This Kaal is indicated in Shwasa, Kasa, Trishna, Hikka, Chhardi and Visha where continuous Vegas is produced. Aushadha is given several times to ensure that it has a long-lasting impact. Faster alleviation comes from sublingual absorption. Therefore, in this Kaal Aushadha can be used in life-threatening diseases.

Indications- $\{$ Fig. 10$\}$

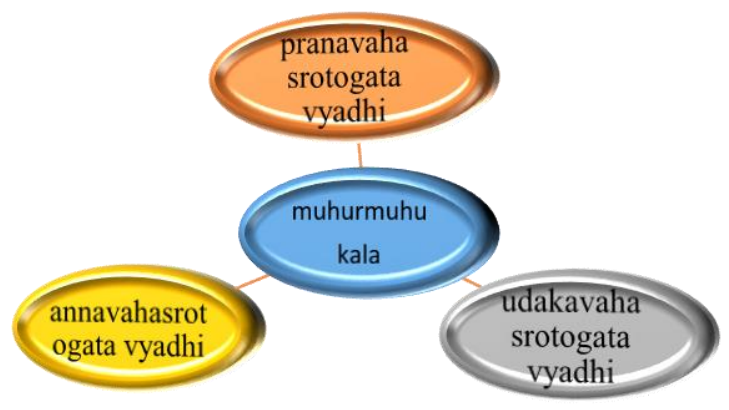

$\{$ Fig.10\}

\section{Nishi Kaal-}

Nishi Kaal is the period following the digestion of the evening meal. The same is said by Acharya Indu. It is 
an Anannavastha, according to Sharangadhara. For Anulomana and Brimhana, this Kaal was built.

Synonyms -Swapnakale, Ratre.

Mode of Action of Bhaishajya -In this Kaal the Bhaishajya takes a selective approach to the Urdhvajatrugata sections. The Shamana Aushadhai achieves Chiraparinamana (long-lasting action) since no food is consumed till the next morning. Urdhwajatru (Murdha) is the place of Prana Vata. As a result, medicine given in this Kaal affects Prana Vata as well.

Indications $-\{$ Fig. 11$\}$

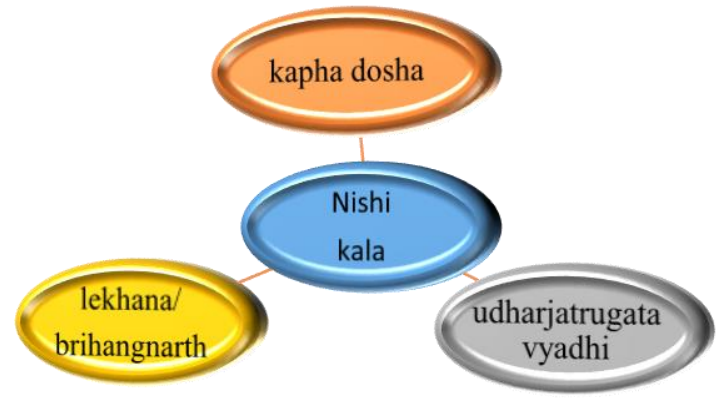

\{Fig.11\}

Many medications' effectiveness, according to contemporary research, vary depending on the dosage administration time related to a 24-hour biological rhythm controlled by the circadian clock. Circadian rhythms are self-sustaining endogenous oscillations occurring in 24 hours. ${ }^{17}$ The circadian rhythms are related to the normal sleep-wake cycle is influenced by our genetic makeup and hence, affects the body's functions day and night (24-hour period) ${ }^{18}$. Suprachiasmatic nuclei (SCN), which are found in the hypothalamus and pineal gland, regulate this rhythm. The circadian clocks in cells, tissues, and organ systems are regulated by this master clock network. The Chrono pharmacologic approaches tend to reduce the side effects and to make the drug more bioavailable. The conventional homeostatic approach is replaced by the proper study of Chrono pharmacology. Diseases, such as hypertension, asthma, peptic ulcer, arthritis, etc. follow the body's circadian rhythm ${ }^{19}$. The Chrono pharmacological principle is used in the ther- apy of Myocardial Infarction, diabetes, hypertension, bronchial asthma, arthritis, hypercholesterolemia, etc. Many functions of the human body vary considerably in a day. These variations cause changes both in disease state and in plasma drug concentrations. The dependence of bodily functions in certain disease states on circadian rhythm is well known. ${ }^{20}$ Several hormones are released by the brain in the morning, while others are released during sleep like growth hormone, melatonin, prolactin, luteinizing hormone, secretion peak during sleep. Cortisol, reninangiotensin is a peek at in the morning. late night gastric acid secretion is on a high level.

Aushad Sevana Kaal comparative to Chrono therapeutics

In Ayurveda, Aushad Sevana Kaal has a major role while treating a patient as well as modern science explain Chrono therapeutics. But in modern science, it is not considered so in all diseases. Ayurveda classics say that Kaal is Svyambhu that's why Vaidya first considered Kaal. In modern science, Circadian rhythms exist in pathological stages of the disease, just as they do in physiological processes. Chrono therapeutics have been shown to have potential benefits in the treatment of a variety of disorders.

Nishi Kaal in Urdhavjatrugata Roga: The worst symptom of allergic rhinitis is reported frequently in the morning. To manage morning discomfort, modern science recommends taking a long-acting antihistamine at night rather than in the morning, depending on the condition. As similar to that, Pritisyaya/Pinas is considered as one of Udhrav Jatrugat Vyadhi and also Prana Vata impairment will be there. In Ayurveda for Urdhavjatrugata Roga medicine will be administrated at Nishi Kaal and for Prana Vata impairment Acharya Shadangdhar quotes Syamadhobhakta Kaal. Here in Pratisyaya, this Nishi and Sayam Adhobhakt Kaal Aushadhaa Prayoga exhibits its mode of action through Chiraparinama Karma. This Chiraparinama Karma is due to the absence of food till the next morning. Urdhvajatrugata Roga is a vast area that includes more diseases includes Kasa, Swasa Shiroroga, Chakshu Roga etc. Specific disease based Aushadha Prayoga can also be 
seen as like Shwas, there is specially mentioned to taken Aushadha on Muhurmuhura Kaal. Also, for Pranavata vitiation, Sagrasa and Grasantra Kaal are mentioned. In Hikka only Acharya Vagbhatt mention Smudaga Aushadha Sevan Kaal So based on Yukti, we should select the appropriate Kaal.

Muhurmuhu Kaal in Shwas Roga: Asthma attacks come about 50-100 times more at night and early morning rather than the daytime. In asthmatic patients, bronchial constriction is more likely to develop in the morning is due to the level of some hormones in the body. Cortisol (an anti-inflammatory chemical) levels will be higher while we woke up and it reaches a lower range at midnight and histamine (a bronchoconstriction mediator) concentrations also peaked up around 4:00 a.m. This is the reason behind early morning bronchoconstriction. Modern science, in the case of asthma, advised using asthma inhalers more frequently during the period of asthmatic attack. In Ayurveda also, all Acharyas specifically advised $\mathrm{Mu}$ hurmuhu Kaal Aushadha Prayoga for Shwas Roga i.e., at Vega Avastha and to produce rapid relief in symptoms. Also, Muhurmuhu Kaal is mentioned for Visha, Chardi, Hikka.

\section{Adho and Madhyobhakta Kaal in Shoolawstha-} Non-steroidal anti-inflammatory drugs (NSAIDs), such as ibuprofen, may be more helpful at relieving pain in people with rheumatoid arthritis and other painful joint conditions if taken at least 4 to 6 hours before the pain peaks. If arthritis patients have a very high level of suffering in the morning, using NSAIDs before bedtime will be more beneficial. But in Ayurveda, the concept is a little different from modern science. In modern science, they gave symptomatic relief but, in the Ayurveda, treatment will be based on Dosha vitiation. If pain is there, then definitely Vata vitiation will be there i.e., Without Vata Dosha, pain cannot occur. Ayurveda mainly stresses on pacification of vitiated Dosha as the first line of treatment. Due to Vata vitiation, two types of Shoola mention in the literature. Shoola in Amavata is considered as Amaja Shoola. Amaavstha is a present due to a disturbance in Agni. The presence of Ama is indicated by Mandagni and Mandagni happens because of Samana Vayu Vikruti. Ultimately, Mandagni leads to Ama formation. By that, Samana Vata involvement will be there in Amaja Shoola. In Saman Vayu Vikriti, Acharya says Madhydho (Madhyabhakt) Kaal is for drug administration and in other joint disorders where Niramja Shoola is present we considered Vyanvayu Vikruti because of Acharya says Vyan Vayu Sarvdeh Sanchari. Then we considered Pratha Adhobhakta Kaal for drug administration.

Adhobhakta Kaal in Hridya roga -The onset of cardiovascular disorders such as Stroke, Myocardial infarction, acute cardiac arrest, Hypertension are more likely in the early morning due to release of catecholamine, cortisol, increase in platelet aggregation, vascular tone and heart rate surge. It typically peaks in the middle to the late time of the day, decreases in the evening and all will be at a lower range while sleeping. Blood pressure and heart rate are high during the hours of 6.00 a.m. to 12.00 noon. So, the risk of heart attack also appears greater in the early morning. There are currently antihypertensive pharmaceuticals on the market that are Chrono treatments with innovative drug delivery systems, releasing drugs during the hours of 6 a.m. and noon after pill administration at 10 p.m. Comparative to this in Ayurveda, Hridya and Sarva Sharir are the site of Vyan Vayu. So, all heart diseases are considered under Vyan Vayu Vikruti. Acharya mentions that the appropriate Kaal for the administration of medicine for Vyan Vayu Vikruti is Adhobhakta Kaal on both morning and evening. This is the time that seems to have increased blood pressure, so the administration of medicine at the appropriate time helps to maintain blood pressure. In Astanga Sangrha Acharya Vagbhatt says in Hridya Roga gave treatment in Grasantra (medicine between of two bolus) Kaal also.

Abhakta Kaal in Pitta Utklesha Vyadhi - In peptic ulcer, stomach acid causes worsening of pain during digestion. In the case of duodenal ulcer, the patient feels pain after 3- 4 hours after stomach acid release is highest at night, it is widely known that individuals with ulcers often have the most pain towards the time they go to bed. The order in which ulcer treatments are given has a substantial impression on their heal- 
ing effect. It is more effective to take these medications before going to bed or before food. In modern science, conventional $\mathrm{H} 2$ blockers Once-daily (Ranitidine, cimetidine, famotidine) is given in the early morning and evening time before food. Acidity is commonly aggravating in the early morning time, so a Proton pump inhibitor is indicated to give on empty stomach for a better result. While we look into Ayurveda, Nirannam(abhakta) Bhakta Kaal is indicated in Kapha and Pitta Utklestha Vyadhi such as Kaphaj Kasa, Adho and Urdha Amlapitta etc. Then we considered in both Vyadhi medicine is administered at empty stomach for a better outcome. Kaphanubandhi Amlapitta is commonly aggravated at early morning time so when follow Aushadha Sevan Kaal in this as a Sanshodharth or Sanshamnarth Aushadha is administrated before food to get better relief due to direct contact of Aushadha with digestive fire.

Abhakta Kaal in Prameha: In IDDM, it's advised to take insulin injection before food ${ }^{21}$ and also oral medications(metformin) is advised after food to control blood sugar level in modern science. Likewise, in the case of vitiated Kapha, it's mentioned as Abhakta (on empty stomach) for Aushadha Prayoga, as Prameha is the Kapha vitiated Roga, it's preferable to give medications on empty stomach than by the direct contact of medicine with Agni without the hindrance of food the action of the drug will be faster. At the same time, Astanga Sangraha mentioned Adhobakta Kaal for Kaphaj Vyadhi.

\section{CONCLUSION}

Though chronotropic has received a lot of attention in academic circles, it is still ignored in clinical practice. Ayurvedic medicine is far more concerned with the timing of medicinal administration. Clinically, the significance of Aushadha Sevana Kaal are more cardinal, as without it all the medicine and food will be for naught. The Bhaishajya Kaal explained by Acharyas seems to be based on the routine we follow in a day from morning to night along with the predominance of Dosha. Oral administration is the cornerstone of all Kaal However, it should not be used in an emergency. Medicines should be taken with fluctuations as per the biological clock of the body. Meanwhile, it looks like the timing of drug administration in disease therapy has a major impact on treatment success. Chrono therapy is a significant area of research that is still being pursued, but it is not often used in inpatient care. But in Ayurveda Bhaishajya Sevan Kaal is a more concerned subject while treating disease. Bhaishajya Sevan Kaal can also be helpful in the development of new methods for treating both traditional and modern lifestyle illnesses. In this study, in comparison with both sciences, we got both similarities and dissimilarities too in Aushadha Prayoga Kaal. Both sciences are standing on their principle, but the aim is to increase the treatment efficacy and to minimize drug toxicity. So, it's more important that we should take account of Aushadha Prayoga Kaal while drug administration. As a result, a Vaidya with a thorough understanding of Bhaishajya Sevan Kaal can treat patients more effectively and achieve better disease outcomes.

\section{REFERENCES}

1. Sharma.R.K, Dash.B (editor), Charaka Samhita, Vimana sthana, chapter 8, verse no.125, Varanasi: Chowkamba Sanskrit Series; Reprint 2008; 279.

2. Murthy. K.R.S. Susrutha Samhita, Sutra sthana, chapter 6, verse no.3, Varanasi: Chowkamba Orientalia; Reprint 2008; 36.

3. Murthy. K.R.S. Commentary: Dalhana on Susrutha Samhita, Sutra sthana, chapter 6, verse no.3, Varanasi: Chowkamba Orientalia; Reprint 2008; 36.

4. Sharma.R.K, Dash.B (editor),Charaka Samhita, Vimana sthana, chapter 1, verse no.6, Varanasi: Chowkamba Sanskrit Series; Reprint 2008; page no.126.

5. Sharma.R.K, Dash.B (editor),Charaka Samhita, chikitsa sthana, chapter 30, verse no.297-298, Varanasi: Chowkamba Sanskrit Series; Reprint 2008; 204.

6. Dr Anantram Sharma, Sushruta samhita-Hindi commentary, Uttartantra, Swasthopakrama Adhyay., Chaukhambha Surbharti prakashan; Varanasi, 1st Edition 2013; Uttartantra, 64-65: 813.

7. Paradkar HS, Ashtang hrudaya, Sutra Sthana, Doshopakramaniya adhyaya, Chaukhambha Surbha- 
rati Prakashan, Varanasi, reprint edition, 2002; 38th shloka: 219.

8. Shri Govardhan Sharma Chagaani, Ashtang Sangraha, Ayurved Martand Tika,-Yadavji Trikamji Acharya, Sutrasthan, Kashi Sanskrit Granthmala, 23/13-21: 210-212.

9. Pt. Sharangdhar Acharya, Sharangdhar Samhita, Pratham Khand, Dwitiya Adhyaya Pt. Parasurama Sastri, Chaukhamba Orientalia, Varanasi, 7th Edition, 2008; Shlok no,2-12: 18.

10. J Sajan*, TA Cinu, AJ Chacko, J Litty and T Jaseeda Chronotherapeutics and Chronotherapeutic Drug Delivery Systems Tropical Journal of Pharmaceutical Research, October 2009; 8 (5): 467-475.

11. Traynor K, Newton DW, Hrushesky JM, Reiter RJ. A pharmacist's primer on chronotherapeutics. American Pharmacy. 1992; NS32(3): 261-269.

12. Benedetti F, Barbini B, Fulgosi MC, Colombo C, Dallaspezia S, Pontiggia A, Smeraldi E (December 2005). "Combined total sleep deprivation and light therapy in the treatment of drug-resistant bipolar depression: acute response and long-term remission rates". The Journal of Clinical Psychiatry. 66 (12): 1535-40. PMID 16401154

13. Sharma.R.K, Dash.B (editor), Charaka Samhita, chikitsa sthana, chapter 30, verse no.298, Varanasi: Chowkamba Sanskrit Series; Reprint 2008; 204

14. Srikantha Murthy KR (2001) Ashtanga Sangraha, Sutrasthana (1stedn). Delhi, Chowkhamba Sanskrit Pratishthan, 428. http://www.vedicbooks.net/astangasamgraha-vagbhata-volume-p-13440.html

15. Dr Anantram Sharma, Sushruta samhita-Hindi commentary, Uttartantra, Swasthopakrama Adhyay., Chaukhambha Surbharti prakashan; Varanasi, 1st Edition 2013; Uttartantra, 64-65: 813.

16. Pt. Sharangdhar Acharya, Sharangdhar Samhita, Pratham Khand, Dwitiya Adhyaya by Dr Bhramanand Tripathi, Chaukhamba shurbharti Prakashan, Varanasi, 7th Edition, 2008; Shlok no, 3-4 page no 23.

17. http://www.iosrjournals.org/iosr-jpbs/papers/Vol4issue4/I0444553.pdf?id=4769 Dr Archana R. Belge1, Dr Omprakash W. Talokar2, Dr Raman S. Belge3: Critical Study of Aushadhi Sevana Kala with special reference to Chronopharmacology IOSR Journal of Pharmacy and Biological Sciences (IOSR-JPBS) ISSN: 2278-3008. Volume 4, Issue 4 (Nov. - Dec. 2012), PP 45-53.
18. Evans RM, Marain C. Taking Your Medication: A Question of Timing. American Medical Association: 1996:3-8.

19. J Sajan*, TA Cinu, AJ Chacko, J Litty and T Jaseeda Chronotherapeutics and Chronotherapeutic Drug Delivery Systems Tropical Journal of Pharmaceutical Research, October 2009; 8 (5): 467-475.

20. Devdhawala Mehul G.* and Seth Avinash K. Current status of chronotherapeutic drug delivery system: An overview J. Chem. Pharm. Res., 2010, 2(3):312-328.

21. https://www.diabetes.org/healthy-living/medicationtreatments/insulin-other-injectables/insulin-routines.

\section{Source of Support: Nil Conflict of Interest: None Declared}

How to cite this URL: Gayatri et al: Role Of Aushadha Sevan Kaal In Ayurveda Comparative To Chrono Therapeutics. International Ayurvedic Medical Journal \{online\} 2021 \{cited August 2021\} Available from: http://www.iamj.in/posts/images/upload/1839 1849.pdf 